\title{
Research on Key Problems of Rural E-commerce Development in Jiangxi County
}

\author{
Peng Xinping, Zhang Xiumei \\ Pingxiang University, Pingxiang, Jiangxi, 337000
}

Keywords: Rural E-commerce, Countermeasures

\begin{abstract}
At present, there are many problems in the development of rural e-commerce in Jiangxi province. Aiming at these problems, in-depth investigation is carried out, and countermeasures are put forward to provide strong intellectual support for the development of rural e-commerce.
\end{abstract}

\section{Introduction}

To conscientiously implement the State Office of the Ministry of Finance and the general office of the Ministry of Commerce "on the development of electronic commerce in rural comprehensive demonstration of the notice", "Jiangxi Provincial Department of Commerce, Department of Finance on e-commerce in rural comprehensive demonstration related work notice" and the spirit of the relevant documents, and promote e-commerce in rural construction, promote agricultural efficiency rural development and farmers income, realize the new development of the rural market circulation system innovation and business model [1]. On the basis of investigating the rural e-commerce in each county of Jiangxi, the Countermeasures for the development of electronic commerce in the county of Jiangxi are put forward.

According to the location and objective requirements of e-commerce development in Jiangxi County, the development of county e-commerce will form "1 or more industrial parks + multi centers + multi points" spatial pattern [2]. The "Industrial Park" refers to the comprehensive e-commerce industrial park at the county level. The center refers to the e-commerce incubator of every township, and the "multi point" includes all the village level e-commerce service stations.

\section{Comprehensive Industrial Park of Electronic Commerce at the County Level}

The electronic commerce comprehensive industrial park is divided into electronic commerce public service center, specialty products $\mathrm{O} 2 \mathrm{O}$ Experience Hall, training center, business office center, warehouse distribution center, operations center, Taobao County Rural County post operation center, Jingdong County Service Center, built B2C platform County Service Center, tourism e-commerce service center and the cross-border e-commerce service center.

Integration of e-commerce enterprises, warehousing logistics, product testing, supporting life services, and actively create a comprehensive e-commerce Industrial Park. To our county as the center, the radiation surrounding provinces, city and county, forming a business supply circle, to the county to create an e-commerce distribution center, and gradually formed covering the business enterprise base, training base, service outsourcing base, business incubators in electronic commerce in heart city.

\section{Ecommerce Industrial Agglomeration Area}

The counties according to their own resources, and actively build e-commerce industry industrial agglomeration, agricultural products e-commerce industry gathering area, cultural tourism e-commerce industry gathering area, e-commerce industry gathering area and apparel products. 


\section{Layout of E-commerce Network}

The implementation of e-commerce in rural comprehensive demonstration system construction, the completion of 1 or more County e-commerce into the rural comprehensive service center; a plurality of township (town) electronic commerce into the rural comprehensive service station; a plurality of e-commerce into the village rural comprehensive service outlets, the formation of the County Service Center, township, village service station service three rural electronic commerce service system. Use of information sharing, small pieces of mail, charge payment, online purchasing and other functions, and gradually improve the standard of logistics warehousing, distribution, electricity network, training services, agricultural enterprises docking, quality supervision, networking channels and other infrastructure elements, make e-commerce play a positive role in promoting rural economic development, promote the upgrading of agricultural enterprises, strengthen the rural business entities, to solve the "last mile" service to farmers, cultivate new growth points for rural economic development, stimulate the power storage [3].

\subsection{Electronic commerce county-level operation center}

\subsubsection{County-level operation center of Alibaba}

With the strategic cooperation with the Alibaba group, the construction of the rural Taobao service station is carried out in the counties, and the county operation center of Ali is built in the demonstration base. Relying on Ali's resources, platform support, advanced technology and brand effect, we set up an e-commerce service network in the rural areas of the county, such as online sales, purchasing and other e-commerce, and expand the depth of e-commerce and related services in the rural areas and services. The two-way circulation of "net goods to the countryside" and "agricultural products entering the city" can be achieved in all counties and rural areas, so as to solve the problem of rural hard to sell, increase farmers' income and narrow the gap between urban and rural areas.

\subsection{2 "Rural e post" county-level Service Center}

In cooperation with postal service, rural e postal projects constructed by postal service will operate 1 or more rural e postal county service centers and multiple rural e postal stations according to the requirements of "high starting point, high standard and high quality".

Through the construction of "rural e post" the county service center and rural service station, popularize knowledge of electricity providers to farmers to provide online purchase and sale of goods, collecting fees, logistics package generation investment and collection, inclusive financial services, so that the villagers can enjoy adequate out of the village to pay for utilities, communication fees, buy train, automobile, air tickets and convenience. Through helping farmers to withdraw money, providing small access and other financial services, we create a two-way circulation platform of "agricultural products entering cities and industrial products going to the countryside", promoting convenient services to villages and towns, and achieving equalization development of urban and rural services [4].

\subsubsection{The county-level service center of the Jingdong}

The county service center by the company's own Jingdong model, housing rental, housing decoration, furniture purchases, office equipment and personnel by the company, the human supervisor is responsible for the service center of the village. The country supervisor can divide the division of labor according to the amount of business, and the country supervisor is responsible for the performance of the district and county.

\subsubsection{The self-built B2C platform county-level Service Center}

Large enterprises or e-commerce enterprises set up B2C platform, set up county-level service centers, and set up their own service stations in towns and villages to promote sales products. 


\subsection{Township e-business incubator center}

The township e-commerce incubator center integrates online store operation, e-commerce training, talent incubation, logistics warehousing and other functions. It provides a platform for e-commerce small and micro businesses or young people who aspiring to develop e-commerce, and actively explore new ways suitable for farmers to become rich. The township e-commerce incubator center is promoting the characteristic agricultural and sideline products, tourism resources and industrial products, and so on. We should intensify efforts to guide the leading businesses, tourism businesses, professional cooperatives, family farms and other new agricultural operators and farmers to participate in e-commerce transactions.

\subsection{E-commerce rural service station layout}

Actively cooperate with ALI, postal, Beijing East, suing and other enterprises to build a rural e-commerce service platform by entrusting a third party. Make full use of rural postal service stations, supply and marketing of agricultural cooperatives, agricultural stores, thousands of villages and township farm shop business center, the activity center of existing resources and gradually establish a rural village service station, Taobao e post rural village service station, service station for Jingdong and self-built B2C platform service station, and gradually realize the production and life of rural residents "consumer Internet, information products, home appliances, express net sales".

\subsection{E-commerce demonstration town, demonstration village}

In order to further promote the development of rural e-commerce, we should strengthen the training of rural e-commerce demonstration villages and towns, and continuously improve the level of rural e-commerce construction. The government introduced the "county rural e-commerce demonstration enterprises, demonstration villages and create measures", the annual award show Fan Town, model village, a typical, held in recognition of the general assembly and the exchange of experience, to create a strong atmosphere of e-commerce in rural areas, to further promote the development of e-commerce in rural counties.

\section{Layout of E-commerce Platform}

\subsection{Encourage large enterprises to establish an e-commerce platform}

Key support to build their own B2C site local large enterprises, encourage commercial enterprises, manufacturing enterprises to establish $\mathrm{B} 2 \mathrm{~B}$ agricultural business platform, B2B agricultural products business platform, B2B platform, O2O food distribution of agricultural business platform, agricultural Internet financial platform and three party e-commerce platform, and gradually integrate the existing products and services resources.

\subsection{Vigorously develop the existing e-commerce platform}

It focuses on speeding up the construction of e-commerce platform on the same side of the city, and focuses on supporting local information portals to extend the development of large-scale professional e-commerce platform integrating transaction, payment and information services. The large-scale express and logistics enterprises that support the support of the conditions develop the regional network shopping platform relying on the advantages of logistics distribution.

\subsection{The establishment or introduction of integrated e-commerce platform, industry e-commerce platform}

Relying on the industrial advantages of the region, we should actively guide the existing industry information service platform to extend the e-commerce platform integrating transaction, payment and information services, and build a number of comprehensive or industrial e-commerce platforms.

\subsection{Strengthen cooperation with the third party e-commerce platform}

Enterprises are encouraged to use the existing e-commerce platform for network sales. 
Enterprises can make full use of Taobao C2C platform, Alibaba domestic station, Huicong network and other domestic B2B platform, Tmall, Jingdong, Dangdang, Suning, vip.com, Amazon and other B2C e-commerce platform to carry out network sales. With the Alibaba, Jingdong and other e-commerce giants to establish strategic cooperation relations, promote Ali and Jingdong landing in the region. In combination of industry characteristics, the integration of products and resources, in the "Taobao Ali characteristics museum building featured Museum; establish specialty shop in the Jingdong, Jingdong established Ali mall; the line in the local museum; using the mature platform, driven by the county network sales, help the traditional enterprise transformation and upgrading of the electricity supplier.

\subsection{The establishment of $\mathrm{O} 2 \mathrm{O}$ e-commerce operation platform}

Combined with the development status of local and surrounding business enterprises, we encourage traditional business enterprises to live offline, and maximize user experience and enhance competitiveness. Product brand promotion and customer service on the line, to create a large location of the $\mathrm{O} 2 \mathrm{O}$ trading enterprise trading platform. We should increase community electric $\mathrm{O} 2 \mathrm{O}$ stores, encourage local electric business enterprises and community convenience stores to cooperate, develop fresh agricultural products, "online subscription store" business, and explore the online marketing and offline experience of fresh urban produce, the wireless mode of urban life. Catering, hotel, entertainment, tourism enterprises can be located in the $\mathrm{O} 2 \mathrm{O}$ platform, with the help of $\mathrm{O} 2 \mathrm{O}$ platform to achieve online payment, offline consumption.

\subsection{Construction of tourism e-commerce platform}

We will open up a multimedia portal for the government's tourism services, and build a tourism e-commerce platform guided by intelligent tourism. Integrating tourist resources such as scenic spots, Gaestgiveriet Hotel, travel agencies, featured products, tourist commodities and original eco cuisine, we have established a resource database for a complete tourism element, supporting multiple access modes and serving the public in the all-round way. The realization of tourist attractions, online booking, the opening of the hotel, hotel and other network information query and transaction functions.

\subsection{Encourage enterprises to build mobile e-commerce service platform}

Enterprises should be encouraged to establish the WeChat public platform and carry out WeChat marketing. To encourage individuals, individual businesses and enterprises to actively establish WeChat public platform, keep up with the pace of network development, focus on publicity and promotion of mobile client; encouraging the use of mobile phone and tablet computer and other smart mobile terminals, in public utilities, transportation and tourism, leisure and entertainment, home affairs, employment market and other fields; the development of mobile payment service city, convenience services, information services and business services.

\section{E-business Operation Mode}

\section{1 "B2C website + village service station purchase + farmers" model}

In order to attract more rural consumers online shopping, the establishment of a rural village service station, Taobao e post rural village service station, Suning self-service stations and other village service station; at the same time can create local $\mathrm{B} 2 \mathrm{C}$ platform website, all kinds of resources needed for production and life of farmers in the integration of the site (including the life and agricultural products and the payment of public utilities and financial etc.). Make full use of the village service station to help the villagers to buy a single purchase, the village service station to extract a certain proportion of the transaction amount as commission.

\section{2 "O2O+B2C" model}

We should give full play to the advantages of entity stores and promote the development of O2O mode of rural electric business, such as learning Jingdong service station and Suning self service 
station, etc., all entities can take $\mathrm{O} 2 \mathrm{O}$ mode to publicize and sell. We can establish online shopping mall, transform Township and village stores, information service stations, convenience stores, small supermarkets and so on, and upgrade to "offline $\mathrm{O} 2 \mathrm{O}$ village service platform" experience shop. In logistics, we can use village stores or convenience stores, and choose a large convenience store for each township as the town village logistics distribution center, so that the logistics terminal will arrive in the village.

\subsection{APP model of agricultural products}

The APP system of agricultural products is established. Farmers can publish their products in the field by locating the cell phone, and then can directly communicate with urban consumers. City consumers through APP of agricultural products information to purchase, ordering, orders, and can make full use of APP to carry out the sale of mobile phone shop.

\subsection{WeChat and micro-blog models}

Electric business enterprises, production enterprises, personal network providers and farmers can make full use of WeChat platform and micro-blog platform to release product information, so as to achieve the purpose of publicity or sale.

\section{5 "Producer + service provider + network distributor" model}

The strategic core of the model lies in the sale of the characteristic agricultural products, which is suitable for the areas with insufficient information, small and medium business and small brands. The core business of the mode is mainly divided into three parts: integration of goods sold, organizing local online merchants to conduct network distribution, standardized and standardized warehousing and delivery services. This model will supply integration, product information, logistics, warehousing, customer service, unified management, to make agriculture and forestry products, producers, processors, distributors to complete their most good work, to improve the efficiency and competitiveness of business operations.

First, it formed the standardization of production and marketing of agricultural products, and changed the traditional and disordered agricultural products into standardized products, so that both parties and supervision institutions could have a reference basis. Two is to promote the production and manufacturing of products towards the direction of standardization, so that the quality of the shop products can be improved effectively.

\section{6 "Producer + e-commerce company" model}

This mode enables the upstream production enterprises and processing enterprises to integrate the agricultural products produced by the electric business enterprises, and then sell them to various places through the electronic business platform such as Taobao. This model is mainly applicable to the areas with insufficient information, low branding and small size of small network business.

\subsection{The model of "agricultural product supplier + alliance + purchasing enterprise"}

The model belongs to the B2B model and builds an e-commerce platform based on bulk agricultural products trading. The alliance plays a core role in the alliance mode, integrate agricultural producers and processors to provide products, brands, agricultural products processing enterprises, large demand for catering enterprises, circulation enterprises and other buyers, but also introduce some provide intermediary services for both supply and demand of agricultural service providers, from a commission from the union deal.

\section{8 "Processing plant + farmers online business" model}

The model is the purchase of goods from the processing plant by farmers, and then sold to all parts of the country through Taobao and other platforms.

\section{9 "Farmers + Internet business" model}

This model is suitable for rural households with special products, and by farmers through Taobao, 
WeChat, micro-blog and other platforms to carry out network sales.

\subsection{0 "Professional market + e-commerce" model}

This pattern is similar to the Yiwu small commodity business model, Qinghe cashmere business model, is the traditional industries and professional markets rely on with great advantages as the basis, to play a leading role in a part of the electricity supplier model; follow the traditional businesses quickly began to imitate, also began to develop the electricity supplier, agglomeration effect.

\section{Distribution of Rural E-commerce Logistics}

Relying on postal, supply and marketing enterprises and social third party logistics network, through policy guidance and market development, we establish a convenient and efficient new rural logistics distribution system. In order to build a rapid circulation channel for the industrial products to go to the countryside and agricultural products into the city, the logistics network of electronic commerce into the countryside is constructed, and the villages and villages in the counties of the county are gradually covered.

\subsection{Speed up the construction of e-commerce logistics infrastructure}

The biggest restriction factor for the development of rural logistics is the lack of rural infrastructure construction. Therefore, the local government, the major logistics enterprises and the electric business enterprises should always consider how to strengthen the local infrastructure construction, including the planning and improvement of roads, networks, communications and logistics facilities. The government can combine all major logistics enterprises and electric business enterprises, relying on their majors, and with their strong financial resources, rationally plan and build local basic logistics facilities. We can give preferential policies and attract large related enterprises to participate in the planning and construction of the local logistics system.

\subsection{Establish "company + brand" e-commerce warehouse logistics distribution center}

The government actively guides the promotion and forms the logistics management model of "company + many brands". The courier services were led by a larger proportion of e post, tact, Shen Tong, the integration of a number of courier companies in the county, the acquisition and retention of shares by way of the establishment of the new company; at the same time keep the other each courier company brand, the formation of "company + business model than the brand". The delivery

units of all express companies are transferred to the Express Center of new company, and the staff of Express Center are responsible for collecting and distributing all express tickets.

\subsection{Establishment of an electric business logistics distribution network in an integrated county and rural area}

In the business incubator center of each county, we set up the postal business storage and distribution center, the village naughty logistics center and the comprehensive express service center. The three center combining network order by the electricity supplier warehouse distribution center distribution through the comprehensive express service center sent to the country; outside the county industrial products delivered to the express service center, through the village of Amoy logistics center and postal logistics, respectively to the rural Taobao service stations and rural stations E; the rural agricultural products by village Amoy logistics center and logistics, through the comprehensive express service center sent to the country.

\subsection{Distribution network distribution in rural areas}

In various rural warehousing and distribution areas, intelligent packaging cabinet, village service station and e post station can be built to radiate surrounding villages, fully integrate existing rural facilities, such as information service stations, snack shops, convenience stores, small supermarkets, etc., to facilitate the collection and delivery of net goods. 
Through the establishment of e-commerce logistics distribution network, it not only saves costs, improves the time rate, but also reduces the cost of express delivery, and builds a fast circulation channel for the industrial products going to the countryside and the agricultural products entering the city, which solves the problem of "the first and the first kilometer" and "the last mile" of the rural e-commerce logistics.

\subsection{Increase the support for logistics express}

In the development of the special funds for the development of rural e-commerce, some funds are arranged to support the development of the key logistics express enterprises. Implementation of logistics and express planning and land security, logistics and express service industry development into the national economic and social development plan; implementation of logistics and express enterprises in the park and electric business enterprises enjoy the same preferential policies, attracting logistics and express headquarters to enter.

\subsection{Building a County warehouse logistics distribution center}

Encourage express enterprises, logistics enterprises to integrate resources, build county professional warehousing and public logistics distribution center, and form the logistics and distribution service system of rural e-commerce. Building a comprehensive freight logistics center at the county level to realize the integration of logistics resources in the county and to build a comprehensive freight logistics center covering the whole county and its surrounding areas. Based on the China post, rookie logistics, one of four links and other courier companies, to fully integrate the existing logistics resources, the establishment of rural logistics distribution network quickly and efficiently, reduce logistics cost, construct the fast channel industrial countryside and agricultural town, rural electricity supplier logistics "first mile" and "the last one kilometer" problem.

\subsection{Improve the rural e-commerce logistics service system}

We should improve the rural logistics and distribution system, and develop logistics and distribution services in collaboration with electronic trading, online shopping and online payment. We should improve the integrated logistics information service platform for rural areas, and promote the development of third party distribution and joint distribution in rural areas. We should vigorously develop the modern logistics industry, strengthen the logistics market rectification, clean up the logistics environment, support and introduce a large number of modern logistics enterprises, and change the "small, scattered and chaotic" situation of the logistics enterprises. The rural e-commerce service system is built around the needs of the integrated services of industrial products to the countryside, agricultural products entering the city and the rural e-commerce. The integration and utilization of existing rural township business center, distribution center, circulation of cyber source, give full play to the township business center sales, distribution, finance, postal services, telecommunications, home appliance maintenance services, establish and perfect to meet the needs of the development of rural e-commerce logistics support service system. We should strengthen the construction of logistics infrastructure, optimize the layout of logistics nodes, plan and build a batch of logistics distribution centers that meet the needs of e-commerce development, and effectively support the e-commerce service system.

The first is to integrate the social logistics information resources and promote the application of advanced logistics technology and equipment, such as the Internet of things. We should vigorously develop the third party and the fourth party logistics, and improve the socialization, organization and information level of the logistics enterprises. Promote the construction of a new logistics distribution center, build a city distribution network covering the city, and gradually extend to the countryside. To speed up the establishment of logistics information network and reduce the cost of logistics.

The second is to promote the interactive development of electronic commerce and third party logistics, to provide rapid and efficient logistics support for online transactions. The key express delivery and distribution enterprises with good reputation, good service and efficient operation will promote the rapid development of network retail. Combined with the city shopping platform, 
promote the development of urban living goods distribution enterprises. We should increase investment in warehousing, distribution centers, logistics centers, wholesale centers, road ports, transfer stations and air-port towns, and introduce advanced logistics management technologies to support e-commerce enterprises in building warehousing, distribution and other logistics facilities. To promote the integration and development of e-commerce and logistics distribution, to establish efficient and smooth logistics and distribution system of electronic commerce.

Thirdly, we should rely on express logistics enterprises, attach importance to the development of rural Internet shopping market, and support the development of online retail platforms and logistics channels for the majority of farmers with the help of logistics network. To promote agricultural products to city and countryside consumer two-way circulation, encourage the production and circulation enterprises in the region to carry out products and agricultural products sales and distribution business using the Internet, explore online to see samples, physical delivery network management pattern.

\subsection{Enhance e-commerce transactions}

First, we should actively publicize and train, create an e-commerce atmosphere and enhance the volume of e-commerce transactions; the two is to actively develop rural industries and achieve the "upward sales" of agricultural products.

\subsection{Strengthen training to promote the construction of the echelon of logistics talents in rural areas}

At present, the rural logistics talents are extremely scarce, and almost no specialized logistics employees are rooted in the countryside. Talent has become a short board that restricts the development of rural logistics. The disadvantages of counties and townships can not attract talents like cities, which requires local governments and major logistics enterprises and e-commerce enterprises to introduce sound policies and regulations. On the one hand the government from the labor and social security, employment subsidies and other aspects to enhance efforts to attract, attract outstanding talent return, encourage home business, increase the introduction of external logistics personnel; on the other hand the government training, industry training, enterprise training, self-learning, cooperation, enterprise cooperation, mutual learning and promotion to promote regional logistics experience, and gradually establish a training system of logistics talents localization. Besides, logistics enterprises and electric business enterprises can also guide employees to work in rural areas from the aspects of salary and career promotion, focusing on the logistics business in rural areas.

In order to promote our province's economic structure adjustment and industrial upgrading, and further enhance our province's market competitiveness, we must seize the initiative, break through and take the lead in the new round of economic restructuring, and accelerate the development of rural e-commerce.

\section{Acknowledgements}

This paper is grateful for the support of Jiangxi Science and Technology Department's Soft Science Research Plan General Project (20161BBA10027) and Jiangxi Humanities and Social Sciences Research Project (GL161010).

\section{References}

[1] Lixin, TANG. Problems in Development of Rural E-commerce and Logistics and Recommendations [J]. Asian Agricultural Research: English Version, 2016(12):41-42.

[2] Yuqing L I, Wang J. Research on the Development Countermeasures of Rural E-commerce under the Background of Internet Finance-Taking Jiaxing as an Example [J]. Agriculture Network Information, 2016. 
[3] Xu Q, Yu Y, Long M. Research on E- Commerce Development and countermeasure in the Rural Areas in Hubei under the Background of the Internet $+[\mathrm{C}] / /$ International Conference on Education, Management, Computer and Society. 2017.

[4] Islam F, Kazal M, Rahman M H. Potentiality on e-commerce in the rural community of Bangladesh [J]. 2016, 27(2):207. 